\title{
Metastatic behaviour of primary human tumours in a zebrafish xenotransplantation model
}

\author{
Ines J Marques ${ }^{1}$, Frank Ulrich Weiss'2, Danielle H Vlecken ${ }^{1}$, Claudia Nitsche ${ }^{2}$, \\ Jeroen Bakkers ${ }^{3}$, Anne K Lagendijk ${ }^{3}$, Lars Ivo Partecke ${ }^{4}$, Claus- \\ Dieter Heidecke4, Markus M Lerch ${ }^{2}$ and Christoph P Bagowski*1
}

\begin{abstract}
Address: ${ }^{1}$ Institute of Biology, Department of Integrative Zoology, University of Leiden, 2333 AL, Leiden, The Netherlands, ${ }^{2}$ Universitätsklinikum Greifswald, Klinik für Innere Medizin A, D-17475, Greifswald, Germany, ${ }^{3}$ Hubrecht Institute \& University Medical Centre Utrecht \& Interuniversity Cardiology Institute of the Netherlands, 3584 CT, Utrecht, The Netherlands and ${ }^{4}$ Universitätsklinikum Greifswald Abteilung für Allgemein,

Viszeral, Thorax und Gefäßchirurgie, D-17475, Greifswald, Germany

Email: Ines J Marques - i.j.marques@biology.leidenuniv.nl; Frank Ulrich Weiss - ulrich.weiss@uni-greifswald.de; Danielle H Vlecken - d.h.w.vlecken@umail.leidenuniv.nl; Claudia Nitsche - claudia.nitsche@uni-greifswald.de;

Jeroen Bakkers - j.bakkers@niob.knaw.nl; Anne K Lagendijk - a.lagendijk@niob.knaw.nl; Lars Ivo Partecke - partecke@uni-greifswald.de; ClausDieter Heidecke - heidecke@uni-greifswald.de; Markus M Lerch - lerch@uni-greifswald.de;

Christoph P Bagowski* - c.p.bagowski@biology.leidenuniv.nl

* Corresponding author
\end{abstract}

Published: 28 April 2009

BMC Cancer 2009, 9:128 doi:10.1 186/|47|-2407-9-128
Received: 20 June 2008

Accepted: 28 April 2009

This article is available from: http://www.biomedcentral.com/I47/-2407/9//28

(C) 2009 Marques et al; licensee BioMed Central Ltd.

This is an Open Access article distributed under the terms of the Creative Commons Attribution License (http://creativecommons.org/licenses/by/2.0), which permits unrestricted use, distribution, and reproduction in any medium, provided the original work is properly cited.

\begin{abstract}
Background: Aberrant regulation of cell migration drives progression of many diseases, including cancer cell invasion and metastasis formation. Analysis of tumour invasion and metastasis in living organisms to date is cumbersome and involves difficult and time consuming investigative techniques. For primary human tumours we establish here a simple, fast, sensitive and cost-effective in vivo model to analyse tumour invasion and metastatic behaviour.
\end{abstract}

Methods: We fluorescently labelled small explants from gastrointestinal human tumours and investigated their metastatic behaviour after transplantation into zebrafish embryos and larvae. The transparency of the zebrafish embryos allows to follow invasion, migration and micrometastasis formation in real-time. High resolution imaging was achieved through laser scanning confocal microscopy of live zebrafish.

Results: In the transparent zebrafish embryos invasion, circulation of tumour cells in blood vessels, migration and micrometastasis formation can be followed in real-time. Xenografts of primary human tumours showed invasiveness and micrometastasis formation within 24 hours after transplantation, which was absent when non-tumour tissue was implanted. Furthermore, primary human tumour cells, when organotopically implanted in the zebrafish liver, demonstrated invasiveness and metastatic behaviour, whereas primary control cells remained in the liver. Pancreatic tumour cells showed no metastatic behaviour when injected into cloche mutant embryos, which lack a functional vasculature.

Conclusion: Our results show that the zebrafish is a useful in vivo animal model for rapid analysis of invasion and metastatic behaviour of primary human tumour specimen. 


\section{Background}

Approximately $90 \%$ of all cancer deaths arise from the metastatic spread of primary tumours [1]. Metastasis formation is a complex, multi-step process in which primary tumour cells invade neighbouring tissues, enter the systemic circulation (intravasate), translocate through the vasculature, arrest in distant capillaries, extravasate into the perivascular tissue, and finally proliferate from micrometastases into macroscopic secondary tumours [2]. Invasiveness and early formation of metastases are the main reasons why for example pancreatic cancer continues to have a dismal prognosis, with a 5 year survival rate of $<5 \%$ and a mean life expectancy of $<6$ month [1].

Zebrafish and their transparent embryos have been employed in several useful models for therapeutic drug research and preclinical studies [3]. High throughput screening (HTS) in zebrafish embryos has been established and is nowadays commonly used for different applications [3-5]. A number of unique features make this animal model very attractive: zebrafish are inexpensive to maintain, breed in large numbers, develop rapidly ex vivo, and can be maintained in small volumes of water [6]. Recently, the zebrafish and its transparent embryos have also come into view as a new model system to investigate tumour development, cancer cell invasion and metastasis formation [7-11]. Mary Hendrix and her group have pioneered the field of cancer cell transplantation in zebrafish embryos and could show that transplanted human malignant melanoma cells are not rejected, survive and even exhibited motility $[12,13]$. Haldi et al. observed the formation of tumour-like cell masses when xenotransplanting human melanoma cells in slightly older zebrafish embryos [14]. Several independent studies have now shown that human melanoma cells and other cancer cell lines are able to induce neovascularization when xenografted in the zebrafish $[14,11,15,16]$.

The role of the small GTPase RhoC in tumour formation, angiogenesis and cell invasion was investigated in realtime in 1-month-old immunosuppressed zebrafish xenografted with the human breast cancer cell line MDA435 [11]. This study achieved high-resolution imaging of the dynamic cell-vascular interface in transparent juvenile zebrafish. All these innovative studies established the use of the zebrafish xenotransplantation model for the analysis of cancer cell lines. In this study we now show that zebrafish embryos can even be used to directly transplant human tumour tissue and primary human tumour cells. Zebrafish embryos thus provide a simple, fast and costeffective method to test the metastatic behaviour of primary tumours in an in vivo vertebrate animal model that also permits high throughput drug screening.

\section{Methods \\ Animal care and handling}

Zebrafish (Danio rerio) (Tuebingen line, alb strain (Albinos) and $\mathrm{Tg}$ (fli1:eGFP) were handled in compliance with local animal care regulations and standard protocols of the Netherlands and Germany. Fish were kept at $28^{\circ} \mathrm{C}$ in aquaria with day/night light cycles (10 h dark versus $14 \mathrm{~h}$ light periods). The developing embryos were kept in an incubator at constant temperatures. The cloche (clo) mutant line has been previously described [17]. Heterozygous fish $\left(\mathrm{clo}^{-/+}\right)$are kept and bred under normal conditions. $25 \%$ of offspring will consist of homozygous $\mathrm{clo}^{-}-$ mutants which lack functional vasculature and circulation $75 \%$ will be siblings with no phenotype. Lack of circulation, an enlarged pericardium and curvature of the tail (at a later time point) are hallmarks of the cloche phenotype.

\section{Cell culture}

EpRas cells were cultured at $37^{\circ} \mathrm{C}$ in DMEM high glucose containing L-glutamine, 4\% FCS and 1:100 Pen/Strep (GIBCO, Invitrogen). PaTu8988T and PaTu8898S cells were cultured in DMEM high glucose, with 10\% FCS and 1:100 Pen/Strep. The EpRas cells were treated with recombinant human TGF- $\beta 1$ (RD systems) at a final concentration of $2 \mathrm{ng} / \mathrm{ml}$. To induce epithelial to mesenchymal transition (EMT), cells were seeded at $70 \%$ confluency in 6 -well plates and media containing TGF- $\beta 1(2 \mathrm{ng} / \mathrm{ml}$ final concentration) was added and replaced every other day for 10 days. After this period, cells were ready for injection.

\section{Cell staining, injections and incubations}

Cells were stained with either CM-Dil (red fluorescence) or DiO (green fluorescence) (Vybrant, Invitrogen). Cells were seeded in 6-well plates, grown to confluency trypsinized (without EDTA for EpRas cells or with EDTA for all other cells used). Subsequently, cells were washed with $67 \%$ DPBS (GIBCO, Invitrogen), transferred to 1.5 $\mathrm{ml}$ Eppendorf tubes and centrifuged $5 \mathrm{~min}$, at $1500 \mathrm{rpm}$. Cells were re-suspended in DPBS containing either CMDil (4 ng/ul final concentration) or DiO $(200 \mu \mathrm{M}$ final concentration). Cells stained with CM-Dil were incubated $4 \mathrm{~min}$ at $37^{\circ} \mathrm{C}$ and then $15 \mathrm{~min}$ at $4^{\circ} \mathrm{C}$. Cells stained with $\mathrm{DiO}$ were incubated $20 \mathrm{~min}$ at $37^{\circ} \mathrm{C}$. After this period cells were centrifuged $5 \mathrm{~min}$ at $1500 \mathrm{rpm}$, the supernatant discarded and cells re-suspended in 100\% FCS, centrifuged again and washed 2 times with $67 \%$ DPBS. Cells were suspended in $67 \%$ DPBS for injection into the embryos. 2 dpf zebrafish embryos were dechorionated and anesthesized with tricaine (Sigma). Using a manual injector (Eppendorf; Injectman NI2), the cell suspension was loaded into an injection needle ( $15 \mu \mathrm{m}$ internal- and $18 \mu \mathrm{m}$ external-diameter). Cells were now injected in 2 dpf albino or $\mathrm{Tg}$ (fli1:eGFP) zebrafish embryos. After injection, embryos were incubated for $1 \mathrm{~h}$ at $31^{\circ} \mathrm{C}$ and checked 
for cell presence at 2 hpt. Fish with fluorescent cells outside the implantation area at $2 \mathrm{hpt}$ were excluded from further analysis. All other fish were incubated at $35^{\circ} \mathrm{C}$ for the following days.

\section{Tissue preparation for transplantation into zebrafish embryos}

Human material from surgical resection specimens was obtained at the Universitätsklinikum Greifswald according to local ethical guidelines and after obtaining informed patient consent. Tumour tissue and control tissue were cut into very small pieces using a scalp blade. A piece of tissue was then transferred to a $2 \mathrm{ml}$ Eppendorf tube, washed with 67\% DPBS and stained with 1:500 CMDil. The tissue was incubated for $6 \mathrm{~min}$ at $37^{\circ} \mathrm{C}$ and 20 min at $4^{\circ} \mathrm{C}$. Washing procedures were the same as mentioned above for the cells. Before transplantation small pieces of stained tissue were further disaggregated using Dumont forceps (No.5) into a relative size of $1 / 5$ to $1 / 2$ the size of the yolk. Tissue pieces with the correct size were transferred to agarose plates in which the embryos were laying, ready for transplantation. For tumour and control transplantations, a glass transplantation needle was used to transfer the tissue into the yolk. With the glass transplantation needle a piece of tissue was picked up, put on top of the yolk and then pushed inside. The yolk usually sealed itself and in the majority of embryos, the tumour remained in the yolk. After transplantation, embryos were incubated for $1 \mathrm{~h}$ at $31^{\circ} \mathrm{C}$, then embryos were checked for presence of tissue and incubated at $35^{\circ} \mathrm{C}$ for the following days.

\section{Cell dissociation from tissue}

Tissue samples were cut in very small pieces using a scalp blade. Cut tissue pieces were then transferred to $6 \mathrm{ml}$ glass containers with $3 \mathrm{ml}$ isolation media (180 ml DMEM high glucose, $20 \mathrm{ml} 100 \mathrm{mM}$ HEPES, $46 \mathrm{ml}$ 5\% BSA) and Collagenase (Invitrogen) ( $50 \mu \mathrm{l}$ of a $6 \mathrm{mg} / \mathrm{ml}$ stock solution for each $12 \mathrm{ml}$ of isolation media). Tissue was incubated in a water bath for $15 \mathrm{~min}$ at $37^{\circ} \mathrm{C}$. The supernatant was decanted and tissue pieces were cut further into smaller pieces using a scalp blade. Tissue pieces were again incubated $15 \mathrm{~min}$ at $37^{\circ} \mathrm{C}$ in $3 \mathrm{ml}$ isolation media with collagenase. Afterwards tissue pieces were transferred to $15 \mathrm{ml}$ falcon tubes and cells were dissolved by pipetting up and down through serial cut blue pipette tips ( 5 different diameters). The cell suspension was now filtered through 2 sheets of gaze, into $2 \mathrm{ml}$ Eppendorf tubes and centrifuged $5 \mathrm{~min}$ at $1500 \mathrm{rpm}$. The supernatant was discarded and cells re-suspended in isolation media. The described procedure was then repeated once. For injections, cells were stained with either CM-Dil or DiO and injected into 2 dpf zebrafish embryos, as described above.

\section{Western-Blotting}

Pancreatic cancer cell lines PaTu-S and PaTu-T were lysed in iced Triton-X-100 lysis buffer $(0.1 \%)$ containing protease inhibitors $(1 \mathrm{ml} / \mathrm{mg}$ tissue, $10 \mu \mathrm{g} / \mathrm{ml}$ aprotinin, 10 $\mu \mathrm{g} / \mathrm{ml}$ leupeptin, 0,01 $\mathrm{M}$ sodiumpyrophosphate, $0,1 \mathrm{M}$ sodiumfluoride, $1 \mathrm{mM}$ dihydrogenperoxide, $1 \mathrm{mM}$ L-phenyl-methyl-sulfonyl-fluoride [PMSF] and 0,02\% soybeantrypsininhibitor). Protein concentration was determined by a modified Bradford-assay (Bio Rad Laboratories, München, Germany) and equal amounts of protein were used in subsequent experiments. Cell lysates were separated by SDS-PAGE on a 7.5\% polyacrylamide gel in a discontinuous buffer system and gels were blotted on nitrocellulose membranes (Hybond C, GE Healthcare Europe $\mathrm{GmbH}$ ). After overnight blocking in NET-gelatine (10 mM Tris/HCl pH 8.0, $0.15 \mathrm{mM} \mathrm{NaCl}, 0.05 \%$ TWEEN $20,0.2 \%$ gelatine) immunoblot analysis was performed followed by enhanced chemoluminescence detection (GE Healthcare Europe $\mathrm{GmbH}$ ) using horseradish peroxidase coupled sheep anti-mouse IgG or goat anti-rabbit IgG GE Healthcare Europe $\mathrm{GmbH}$ ). Monoclonal E-cadherin antibody (Clone 36), directed against the carboxy-terminus, was purchased from Transduction Laboratories (San Diego, CA, USA) as well as antibodies against $\alpha-, \beta-$, and $\gamma$-Catenin. A polyclonal G3PDH antibody was purchased from Biozol (Eching, Germany).

\section{Immunofluorescence microscopy}

PaTu-S and PaTu-T cells grown on glass coverslips for 24$48 \mathrm{~h}$ were washed 3 times with PBS, fixed for $15 \mathrm{~min}$ in $4 \%$ paraformaldehyde and permeabilised in $0.1 \%$ Triton$\mathrm{X}-100$ for $5 \mathrm{~min}$. Blocking of unspecific binding was achieved by a $1 \mathrm{~h}$ incubation in 10\% Aurion BSA-c (Aurion, Waageningen, The Netherlands). Following a primary antibody incubation over night (dilutions 1:100) and subsequent PBS washing steps detection was performed using dichlortriacinyl aminofluoresceine (DTAF) or Cy3-coupled sheep IgG (dilutions 1:200). Nuclei were stained by a $30 \mathrm{sec}$. incubation with DAPI (1:10000 in PBS). After a final washing step in PBS cell were mounted in Vectashield (Vector Labs, Burlingame, CA, USA). Microscopic Images were taken using an AxioCam digital microscope camera on a Zeiss Axiophot microscope.

\section{In vitro migration assay ("scratch"-assay)}

The scratch-assay was performed as previously described by Liang et al. [18]. Cells were grown to confluency in 6well dishes and mitomycin $\mathrm{C}$ was added at $10 \mu \mathrm{M}$ for $2 \mathrm{~h}$. Then the cell monolayer was scraped in a straight line with a $200 \mu \mathrm{l}$ pipette tip. Pictures of the scratch were taken under an invert Olympus microscope at $0 \mathrm{~h}, 12 \mathrm{~h}$ and 24 h. 


\section{Histology of zebrafish embryos}

Transversal sections at $4 \mu \mathrm{M}$ thickness were prepared as described before [19]. Coupes were directly imaged with fluorescence microscopy or differential interference (DIC) microscopy. After fluorescent pictures were taken, Hematoxylin/Eosin (HE) staining was performed as described earlier [20].

\section{Whole mount immunofluorescence of zebrafish embryos} Zebrafish embryos at $2 \mathrm{dpt}$ were fixed overnight in 4\%PFA in PBS at $4^{\circ} \mathrm{C}$. After fixing, embryos were washed with BSAc 0.1\%-TritonX100 1\% in PBS (blocking buffer; $3 \times 10$ minutes). Subsequently, the embryos were incubated for 2 hrs in blocking buffer at RT. Incubation with the primary antibody (Mouse anti-Proliferating Cell Nuclear Antigen, PCNA, from Zymed Laboratories, 1:100) was done overnight at $4^{\circ} \mathrm{C}$. After washing $(3 \times 10$ minutes $)$ with blocking buffer, embryos were incubated with the secondary antibody (Fluorescein (DTAF)-conjugated AffiniPure Goat anti-Mouse IgG, Jackson Immuno Research Laboratories, Inc., 1:100) for $1 \mathrm{hr}$. and washed afterwards with blocking buffer (3 310 minutes). Embryos were mounted in 3\% methylcellulose to orient them properly for imaging. Imaging was done with confocal scanning laser microscopy (Biorad 1024ES; Software: Biorad Laser sharp 2000).

\section{Imaging, selection and positioning of transplanted zebrafish embryos}

Confocal pictures were taken either with the Biorad Confocal microscope 1024ES (Zeiss microscope) combined with Krypton/Argon laser, or the dual laser scanning confocal microscope Leica DM IRBE (Leica) or with the Nikon TE300 confocal microscope and a coherent Innova 70C laser (Chromaphor, Duisburg, Germany). Pictures were further taken by DIC microscopy using the Axioplan 2 microscope with an AxioCam MR5 camera (Carl Zeiss). Further, fluorescent stereomicroscope pictures were taken with the Leica DFC $420 \mathrm{C}$ camera attached to a Leica MZ16FA microscope. Two hours post implantation the embryos were anesthetized with tricaine and positioned laterally, with the site of the implantation to the top, on $3 \%$ methylcelulose, on a slide with depression. Each time two rows of twenty embryos were screened. Two hours post implantation every embryo that showed cells outside the area of implantation was discarded and not considered for the experiment.

\section{Results}

Tumour cell xenografts in zebrafish embryos

Mouse mammary epithelial cells (EpH4) transformed with oncogenic Ras (EpRas) have been used to establish a mouse tumourigenesis model over a decade ago [21]. In these EpRas cells, TGF- $\beta$ signalling causes epithelial to mesenchymal transition (EMT) which transforms cells to a highly invasive phenotype and enables distant metastasis formation when transplanted into nude mice [22]. Initially, we evaluated metastasis formation using this wellcharacterized system in the zebrafish cell xenograft model. We transplanted fluorescently labelled EpRas cells into the yolk sac of 2 day old zebrafish embryos to study metastatic behaviour in vivo. EpRas cells that had been stimulated with TGF- $\beta$ for 10 days prior to injection, showed metastatic behaviour in the zebrafish, comparable to results previously reported in mice [21-23]. Following EMT the cells invaded embryonic tissue, entered the circulation and homed in at distant tissues and organs. EpRas TGF $\beta$ treated cells were found in blood islands, brain, caudal fin, caudal vein, gill arches, heart, intestine, liver, mandible, optic cup (eye), otic cup, pericardium, somites, swim bladder. However, they had a tendency to invade and home in to muscle tissue, head structures, caudal fin and blood islands (Fig. 1 and Additional File 1). To a lesser extent, we observed invasion of these cells into the liver or other organs of the gastrointestinal tract. In contrast, unstimulated EpRas control cells remained at the place of injection in the yolk and neither invaded the developing zebrafish nor did they enter blood circulation (Fig. 1 and Additional file 2). In three independent experiments the average percentage of migrating cells observed for the EpRas TGF- $\beta$-stimulated cells was $46.6 \%$ (SD +/2.0; p-value < 0.001) compared to $0.5 \%$ (SD +/- 0.7; pvalue $<0.001$ ) for the parental EpRas cells (see Additional file 1). Furthermore, the TGF- $\beta$ stimulated EpRas cells formed tumour cell masses in the developing zebrafish (Fig. 1), which resemble the formation of metastases in nude mice[23]. In the zebrafish, cells begin to invade the embryo already several hours after injection (on average 4 hours post injection)(see Additional File 3) and tumour cell masses are visible as early as 3 days post implantation (dpi).

For optimal visualization, we used the transgenic zebrafish line, $\mathrm{Tg}$ (fli1:eGFP)[11,24], which expresses GFP under the fli1 promotor (an early endothelial marker) and therefore exhibits a green fluorescent vasculature $[11,24]$. In a time lapse movie (see Additional file 4; rate: 1 frame/ minute) we show an example of fluorescently labelled EpRas TGF- $\beta$ cells (3 dpi) which have invaded the zebrafish body, have translocated into the vasculature and have colonized at distant sites in the zebrafish larvae (5 $\mathrm{dpf}$ ). Some cells are visible in the blood stream whereas others have extravasated from the vasculature. Evaluation of metastasis formation in the zebrafish model is therefore significantly faster than in currently used mouse models, where it may take several weeks until metastases become detectable [23]. The sensitivity of the zebrafish tumour xenograft model further allows observation of individual cells and their daughter cells in vivo. 


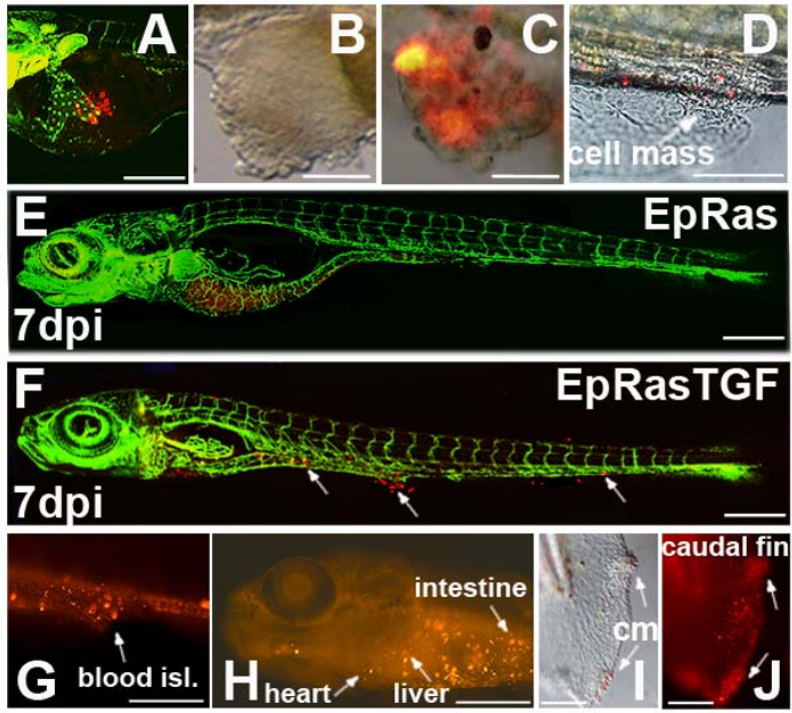

Figure I

Migration and cell mass formation of Ha-Ras transformed mouse mammary epithelial cells injected into the yolk sac of zebrafish embryos. EpRas (parental) and EpRas cells stimulated with TGF- $\beta$ (EpRasTGF) were labelled and ectopically injected into the yolk sac of $2 \mathrm{dpf}$ zebrafish embryos. In A, E and F transgenic zebrafish embryos expressing GFP under an endothelial promotor ( $\mathrm{Tg}$ (flil:eGFP) were used. An example of newly injected EpRas cells at I hour post injection is given in (A). In (B) an ectopic tumour cell mass formed in the yolk sac by EpRasTGF cells is shown. Examples of cell masses formed by EpRasTGF cells at distance from the place of injection are shown for the tail region $(C)$ and blood islands with surrounding ventral fin (D). Pictures in B-D were taken at 3 dpi. While EpRas cells remained in the yolk and never invaded the embryo (E), EpRasTGF cells invaded, migrated and formed distant micrometastases, which are indicated with arrows (F). Red fluorescence of cells is still visible after $7 \mathrm{dpi}(\mathrm{E}, \mathrm{F})$. Images $\mathrm{G}$ to J show tumour cell masses $(\mathrm{cm})$ and migrated cells in blood islands (blood isl.), the liver, heart, intestine and the caudal fin of 6 dpi larvae. Scales shown are for A: $200 \mu \mathrm{m}$; D-H: $600 \mu \mathrm{m}$, for $\mathrm{B}, \mathrm{C}, \mathrm{I}$ and J: $100 \mu \mathrm{m}$. 3D reconstructions of EpRAS and EpRasTGF cells in zebrafish larvae are shown in two supplemental movies (see Additional file 2 and Additional file 3).

We also compared the two established human pancreatic tumour cell lines, PaTu8988-S and PaTu8988-T [25] (referred to herein as PaTu-S and PaTu-T) in their invasive and metastatic potential in a single zebrafish. Both sister cell lines originate from liver metastases of the same human pancreatic adenocarcinoma [25]. E-Cadherin expression in PaTu-S cells (Fig. 2A and 2B(a)) correlates with the maintenance of functional cell-cell contacts (Fig. 2B) and a reduced tendency of cells to migrate (Fig. 2C) $[26,27]$. Whereas PaTu-S cells show localization of E- cadherin $/ \beta$-catenin complexes at the plasmamembrane (Fig. 2B(e)), PaTu-T cells lack E-Cadherin expression (Fig. $2 \mathrm{~A}$ and $2 \mathrm{~B}(\mathrm{~b}))$ and $\beta$-catenin is mainly localized in the cytoplasm (Fig. 2B(d). This observation is paralleled by enhanced migratory capabilities of PaTu-T cells compared to PaTu-S cells, which we confirmed in an in vitro migration assay ('scratch assay' [28] (Fig. 2C and Additional file 5).

We then labelled PaTu-S cells with green fluorescence and PaTu-T cells with red fluorescence. When implanted successively in the yolk sac of the same zebrafish embryo, green PaTu-S cells remained in the yolk, whereas red PaTu-T cells displayed invasion and metastatic behaviour (Fig. 2D and Additional file 1). Similar results were observed when cells were mixed prior to injections (data not shown).

PaTuT cells were found in the brain, caudal vein, gill arches, gut, heart, intestine, liver, operculum, pericardium, somites, swim bladder. They showed a tendency to invade and home in to organs of the gastrointestinal tract. Micrometastasis was often observed in organs such as the liver, the gut and the intestine. Invasion and homing in of these cells into muscle tissue was observed to a lesser extent. This behaviour was qualitative different from what we observed for TGF- $\beta$ treated EpRas cells. We further tested the metastatic behaviour of PaTu-T cells in homozygous cloche mutants (cloche ${ }^{-} /$), which lack a functional vasculature and circulation ([17] Additional File 6). In contrast to control zebrafish, no metastatic behaviour was observed in the cloche $/$ - fish, indicating that the observed invasion/migration of PaTu-T cells indeed involves metastasis formation through the vascular system. Zebrafish were followed until three days post injections (Fig. 2E; see Additional file 1 and see Additional file 7).

\section{Human tumours transplanted into zebrafish display metastatic behaviour}

We then pursued our primary goal to employ the zebrafish also as a simple, fast and effective test system for metastasis formation of primary human tumours. After informed patient consent small fragments of tumour explants from pancreas, colon and stomach carcinoma, as well as tumour-free areas from the same resection specimen were fluorescently labelled with CM-DIL and directly xenotransplanted into the yolk sac of zebrafish embryos. Tumour and non-tumour control cells were followed live by laser scanning confocal microscopy. Tumour cells started to invade the embryo on average 12 hours post injection and micrometastasis formation was visible as early as $24 \mathrm{~h}$ post injection. In parallel, we also investigated and compared the invasive and metastatic behaviour of tumour cells that had been dissociated from 

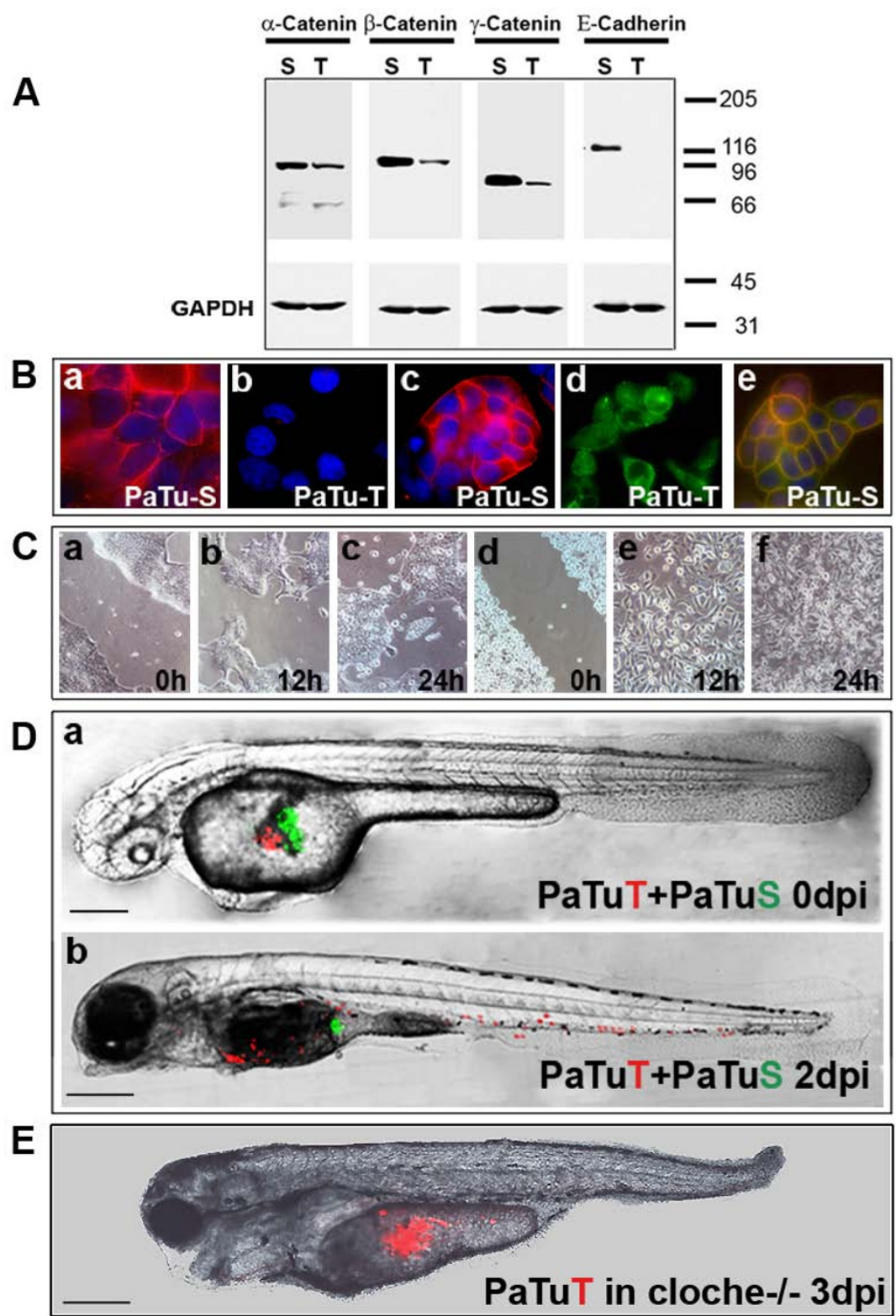

\section{Figure 2}

Implantation of two pancreatic cancer cell lines into the same zebrafish embryo. (A) Western blot analysis shows that PaTu-S but not PaTu-T cells express E-cadherin and both express $\alpha$-, $\beta$ - and $\gamma$-catenin. GAPDH expression is shown as a control. (B) Cellular localization of E-cadherin and $\beta$-catenin was analysed by immunofluoresscence. E-cadherin expression is shown for PaTu-S cells (a) and absence of E-cadherin expression for PaTu-T cells (b). Dapi staining was used to visualize cell nuclei in blue. $\beta$-catenin localization is shown for PaTu-S (c) and for PaTu-T (d). Co-localization of E-cadherin (green) and $\beta$-catenin (red) in PaTu-S cells is indicated by yellow staining of the plasmamembrane (e). (C) An in vitro migration assay ('scratch assay') shows differences in migration of the two cell lines (PaTu-S: a-c and PaTu-T: d-f). Similar results were obtained in four independent experiments. Gap closure (gap width) over time is shown in Additional file 5. (D) Non-invasive PaTu-S cells (green) and invasive PaTu-T cells (red) were implanted consecutively in the same embryo (a and b) (Scales: $250 \mu \mathrm{m}$ (a) and 300 $\mu \mathrm{m}$ (b)). (E) Homozygous cloche mutants [ 17] were injected with PaTu-T cells and followed over time. Shown is an example of a cloche- $/$ - zebrafish at $3 \mathrm{dpi}$ (scale bar: $300 \mu \mathrm{m}$ ). In contrast to control zebrafish none of the tested cloche-/-mutants showed any sign of metastatic behaviour (see Additional file I and Additional file 7). The cloche phenotype and its lack of a functional vasculature and circulation is observable by DIC microscopy (see Additional file 6). 
primary human tumours by collagenase digestion prior to transplantation.

In total, pancreatic tumours of four different patients were analysed. Three had carcinomas of the pancreas head and one had an adenocarcinoma of the ampulla vateri with infiltration of the pancreas (cancer grades and pTMN stages for all tumours are shown in table 1). On average $59.8 \%$ (SD +/- 5.2) of transplanted pancreatic tumour fragments showed invasion and migration in the developing zebrafish (table 1 and Fig. 3). Evaluation criteria for invasion and migration were that at least 5 cells had to be identified outside of the yolk and detectable within the developing zebrafish (table 1). Development of micrometastases was assessed by the presence of daughter cells at 3 dpt. The results are listed in table 1 and in Fig 4 examples of micrometastases in different tissues detected in sections of $5 \mathrm{dpf}$ zebrafish are shown at high resolution (Fig. 4B, C, $\mathrm{D}, \mathrm{G}, \mathrm{H}, \mathrm{K}$ and $4 \mathrm{~L}$ ). An example showing proliferating pancreatic tumour cells and the initial formation of a micrometastasis is given in Fig 5(E). Cell division is further indicated by PCNA immunostaining of invasive tumour cells in the zebrafish embryo (see Additional file 8). After $5 \mathrm{dpf}$ embryos fall under strict local animal experiment regulations, therefore most embryos were not followed for longer periods. It is likely that the number of micrometastases would still increase over time.

Invasive cells were found for pancreatic tumours in blood islands, caudal fin, caudal vein, gut, heart, hindbrain, intestine, liver, mesonephric duct, mesonephric tubule, mandible, operculum, pericardium, somites, swim bladder, for the colon tumour in caudal vein, gut, heart, intestine, liver, pericardium; and for the stomach tumours in the caudal vein, gill arches, heart, intestine, liver, mandible, otic cup, pericardium;

Similar to preferences observed for PaTu-T cells, tumour cells of implanted gastrointestinal tumor tissue fragments had a tendency to invade and home in to organs of the gastrointestinal tract. Micrometastasis were often observed in the liver, the gut and the intestine. Homing in of these cells in muscle tissue and the formation of micrometastasis was rarely observed. Although we observed qualitative differences for the preferential homing in of the two cell lines tested (PaTu-T and TGF- $\beta$ treated EpRAS cells), a future study, with a larger cohort of tumour specimen and tumour types is necessary to determine tumour specific preferences.

Fig 3 shows examples of fish embryos directly after transplantation (A, B) and at 1- and 3-dpt (C-G). Cell invasion and micrometastasis formation of pancreatic tumour cells is clearly detectable $24 \mathrm{~h}$ after transplantation (E). Similar results were also obtained for transplanted tissue frag- ments of a colon adenocarcinoma (43.9\% invasion and migration) and two moderately differentiated adenocarcinomas of the stomach (average 53.5\%, SD +/- 1.2) (p-values in all tumour experiments were $<0.001$ ). As a control for the tumours we used colon and gastric mucosal fragments or peritumoural, non-transformed tissue of the respective tissue explants from the same patients. In the pancreas the non-transformed tissue controls mostly showed histological manifestations of chronic pancreatitis and only one was considered as having a normal pancreatic histology.

Histological sections of control pancreas and of pancreatic cancer tissue of human patients are shown in Fig 3(J, K). In all control transplantations of chronic pancreatitis specimen and of fragments of normal pancreas, colon and stomach tissue cellular invasion and migration was never observed (see Additional file 1 and Fig. 3D, F). In addition, we also tested the metastatic behaviour of a benign tumour. Tissue fragments of adenomateous colonic polyps $(0,4 \mathrm{~cm}$ and $1 \mathrm{~cm})$ were investigated, which had not yet invaded through the lamina muscularis mucosae. No metastasis was observed for either of them in the zebrafish embryo (Additional file 1). Comparable results were seen when cells were dissociated from tumour or control tissue samples prior to their injection into the zebrafish. All four primary pancreatic tumour cells showed cellular invasion and migration with an average of $48.8 \%(S D+/-9.0)$ (see Additional file 1). In the case of dissociated primary colon and stomach tumour cells $44.4 \%$ and $35.3 \%$ of cell injections, respectively, resulted in cellular invasion and migration (see Additional file 1).

Xenotransplantation experiments of tumour fragments as well as the injection of isolated primary tumour cells allowed to discriminate between non-invasive chronic pancreatitis and infiltrating pancreatic adenocarcinoma. In real-time, we show an example of pancreatic tumour cells in the zebrafish 1 day after a pancreatic cancer fragment was transplanted (see Additional file 9). This movie shows circulating tumour cells and tumour cells which have extravasated into the perivascular tissue of a 3 day old zebrafish. A moving primary human tumour cell passing through the caudal vein and into an intersegmental vessel is also visible. In a supplemental movie we show how a pancreatic tumour cell is slowly traversing through the caudal vein of a $3 \mathrm{dpt} \operatorname{Tg}($ fli1:eGFP) zebrafish (see Additional file 10). In Fig 4 histological sections of zebrafish embryos transplanted with a pancreatic human tumour are shown at $3 \mathrm{dpt}$. Examples of micrometastases in the liver (B, C and D) and near the mesonephric duct ( $\mathrm{G}$ and $\mathrm{H}$ ) are shown at higher magnifications. A cell mass is further shown in $\mathrm{K}$ and $\mathrm{L}$. 
Table I: Tumour xenotransplantations into 2 day old zebrafish

\begin{tabular}{|c|c|c|c|c|c|c|c|c|c|c|c|c|c|}
\hline \multirow{2}{*}{ 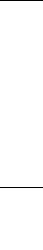 } & \multirow{2}{*}{$\begin{array}{l}\text { Tumour } \\
\text { Transplants } \\
\text { (grade and } \\
\text { pTMN } \\
\text { stage) }\end{array}$} & \multirow{2}{*}{$\begin{array}{l}\text { Number } \\
\text { transplants } \\
\text { (survivors) }\end{array}$} & \multicolumn{3}{|c|}{$\begin{array}{l}\text { Migration [presence of } \\
\text { micro-metastases at } 3 \\
\text { dpi] }\end{array}$} & \multirow[t]{2}{*}{$\begin{array}{l}\text { total } \\
>5 \\
{[\%]}\end{array}$} & \multirow[t]{2}{*}{$\begin{array}{l}\text { Control } \\
\text { Transplants }\end{array}$} & \multirow{2}{*}{$\begin{array}{l}\text { Number } \\
\text { transplants } \\
\text { (survivors) }\end{array}$} & \multicolumn{3}{|c|}{$\begin{array}{l}\text { Migration } \\
\text { [presence of micro- } \\
\text { metastases at } 3 \mathrm{dpi}]\end{array}$} & \multirow[t]{2}{*}{$\begin{array}{l}\text { total } \\
>5 \\
{[\%]}\end{array}$} & \multirow[t]{2}{*}{$\begin{array}{l}\mathrm{p}- \\
\text { value }\end{array}$} \\
\hline & & & $<5$ & 5 to 20 & $>20$ & & & & $<5$ & 5 to 20 & $>20$ & & \\
\hline I & $\begin{array}{l}\text { Pancreas } \\
\mathrm{G} 2 ; \mathrm{T3} ; \mathrm{NI} \\
(I 3 / I 4) \mathrm{RI} \\
\mathrm{MI}\end{array}$ & $80(64)$ & 0 & $\begin{array}{l}20 \\
{[4]}\end{array}$ & $25[20]$ & $70.3 \%$ & $\begin{array}{l}\text { Normal } \\
\text { Pancreas }\end{array}$ & $80(73)$ & 0 & 0 & 0 & 0 & $\begin{array}{l}6.3 \times \\
10^{-5}\end{array}$ \\
\hline 2 & $\begin{array}{l}\text { Pancreas } \\
\mathrm{G} 2 ; p T 3 \\
p N I, p M I\end{array}$ & $60(42)$ & $\begin{array}{l}2 \\
{[0]}\end{array}$ & $\begin{array}{l}18 \\
{[4]}\end{array}$ & $\begin{array}{l}6 \\
{[4]}\end{array}$ & $57.1 \%$ & $\begin{array}{l}\text { Chronic } \\
\text { Pancreatitis }\end{array}$ & $60(50)$ & 0 & 0 & 0 & 0 & $\begin{array}{l}1.1 \times \\
10^{-5}\end{array}$ \\
\hline 3 & $\begin{array}{l}\text { Pancreas } \\
\text { G2; pTI, pNI } \\
(I / I 8) p M I\end{array}$ & $80(46)$ & 0 & $\begin{array}{l}18 \\
{[5]}\end{array}$ & $\begin{array}{l}8 \\
{[7]}\end{array}$ & $56.5 \%$ & $\begin{array}{l}\text { Chronic } \\
\text { Pancreatitis }\end{array}$ & $80(59)$ & 0 & 0 & 0 & 0 & $\begin{array}{l}1.9 \times \\
10^{-4}\end{array}$ \\
\hline 4 & $\begin{array}{l}\text { Pancreas } \\
\text { G3; pT3,pNI } \\
\text { mi }(I I I I) \\
\text { pMI }\end{array}$ & $80(65)$ & 0 & $\begin{array}{l}24 \\
{[6]}\end{array}$ & $\begin{array}{l}12 \\
{[9]}\end{array}$ & $55.4 \%$ & $\begin{array}{l}\text { Chronic } \\
\text { Pancreatitis }\end{array}$ & $80(58)$ & 0 & 0 & 0 & 0 & $\begin{array}{l}5.4 \times \\
10^{-5}\end{array}$ \\
\hline 5 & $\begin{array}{l}\text { Colon } \\
\text { G2; pT3 pNI } \\
(2 / / 4) L N \\
\text { metas. }\end{array}$ & $80(66)$ & 0 & $\begin{array}{l}15 \\
{[7]}\end{array}$ & $\begin{array}{l}14 \\
{[10]}\end{array}$ & $43.9 \%$ & $\begin{array}{l}\text { Normal } \\
\text { Tissue }\end{array}$ & $80(72)$ & 0 & 0 & 0 & 0 & $\begin{array}{l}0.9 \times \\
10^{-6}\end{array}$ \\
\hline 6 & $\begin{array}{l}\text { Stomach } \\
\mathrm{G} 2: p T 3 \text { pN2 } \\
(I / / / 8 L K)\end{array}$ & $80(62)$ & 0 & $\begin{array}{l}23 \\
{[6]}\end{array}$ & $\begin{array}{l}11 \\
{[9]}\end{array}$ & $54.8 \%$ & $\begin{array}{l}\text { Normal } \\
\text { Tissue }\end{array}$ & $80(68)$ & 0 & 0 & 0 & 0 & $\begin{array}{l}2.9 \times \\
10^{-5}\end{array}$ \\
\hline \multirow[t]{3}{*}{7} & $\begin{array}{l}\text { Stomach } \\
\text { G2; ypT2b, } \\
\text { ypN0 }(0 / 20)\end{array}$ & $80(48)$ & 0 & $\begin{array}{l}18 \\
{[5]}\end{array}$ & $\begin{array}{l}7 \\
{[6]}\end{array}$ & $52.3 \%$ & $\begin{array}{l}\text { Normal } \\
\text { Tissue }\end{array}$ & $80(5 \mathrm{I})$ & 0 & 0 & 0 & 0 & $\begin{array}{l}1 \times \\
10^{-6}\end{array}$ \\
\hline & $\begin{array}{l}\text { Primary } \\
\text { tumour cell } \\
\text { injections }\end{array}$ & $\begin{array}{l}\text { Number } \\
\text { transplants } \\
\text { (survivors) }\end{array}$ & \multicolumn{3}{|c|}{$\begin{array}{l}\text { Migration } \\
\text { [presence of micro- } \\
\text { metastases at } 3 \mathrm{dpi}]\end{array}$} & $\begin{array}{l}\text { total } \\
>5 \\
{[\%]}\end{array}$ & $\begin{array}{l}\text { Primary } \\
\text { control cell } \\
\text { injections }\end{array}$ & $\begin{array}{l}\text { Number } \\
\text { transplants } \\
\text { (survivors) }\end{array}$ & \multicolumn{3}{|c|}{$\begin{array}{l}\text { Migration } \\
\text { [presence of micro- } \\
\text { metastases at } 3 \mathrm{dpi}]\end{array}$} & $\begin{array}{l}\text { total } \\
>5 \\
{[\%]}\end{array}$ & $\begin{array}{l}\mathrm{p}- \\
\text { value }\end{array}$ \\
\hline & & & $<5$ & 5 to 20 & $>20$ & & & & $<5$ & 5 to 20 & $>20$ & & \\
\hline I & Pancreas & $80(63)$ & $\begin{array}{l}3 \\
{[0]}\end{array}$ & $\begin{array}{l}38 \\
{[10]}\end{array}$ & $\begin{array}{l}4 \\
{[4]}\end{array}$ & $66.6 \%$ & $\begin{array}{l}\text { Normal } \\
\text { Pancreas }\end{array}$ & $80(69)$ & 0 & 0 & 0 & 0 & $\begin{array}{l}9.1 \times \\
10^{-5}\end{array}$ \\
\hline 2 & Pancreas & $80(66)$ & 0 & $\begin{array}{l}23 \\
{[7]}\end{array}$ & $\begin{array}{l}3 \\
{[2]}\end{array}$ & $39.4 \%$ & $\begin{array}{l}\text { Chronic } \\
\text { Pancreatitis }\end{array}$ & 8072 & $\begin{array}{l}2 \\
{[0]}\end{array}$ & 0 & 0 & 0 & $\begin{array}{l}7.6 \times \\
10^{-5}\end{array}$ \\
\hline 3 & Pancreas & $80(63)$ & 0 & $\begin{array}{l}22 \\
{[7]}\end{array}$ & $\begin{array}{l}6 \\
{[5]}\end{array}$ & $44.4 \%$ & $\begin{array}{l}\text { Chronic } \\
\text { Pancreatitis }\end{array}$ & $80(61)$ & $\begin{array}{l}\text { I } \\
{[0]}\end{array}$ & 0 & 0 & 0 & $\begin{array}{l}4 \times \\
10^{-4}\end{array}$ \\
\hline 4 & Pancreas & $80(63)$ & 0 & $\begin{array}{l}23 \\
{[6]}\end{array}$ & $\begin{array}{l}5 \\
{[4]}\end{array}$ & $44.4 \%$ & $\begin{array}{l}\text { Chronic } \\
\text { Pancreatitis }\end{array}$ & $80(63)$ & $\begin{array}{l}1 \\
{[0]}\end{array}$ & 0 & 0 & 0 & $\begin{array}{l}5 \times \\
10^{-4}\end{array}$ \\
\hline 5 & Colon & $80(65)$ & 0 & $\begin{array}{l}24 \\
{[7]}\end{array}$ & $\begin{array}{l}5 \\
{[4]}\end{array}$ & 44.4 & $\begin{array}{l}\text { Normal } \\
\text { Tissue }\end{array}$ & 80 (59) & I & 0 & 0 & 0 & $\begin{array}{l}2.7 \times \\
10^{-5}\end{array}$ \\
\hline 6 & Stomach & $80(68)$ & 0 & $\begin{array}{l}24 \\
{[6]}\end{array}$ & 0 & 35.3 & $\begin{array}{l}\text { Normal } \\
\text { Tissue }\end{array}$ & $80(69)$ & 0 & 0 & 0 & 0 & $\begin{array}{l}6.8 \times \\
10^{-6}\end{array}$ \\
\hline
\end{tabular}


Table I: Tumour xenotransplantations into 2 day old zebrafish (Continued)

Tumours as numbered in the table: 'Pancreas head carcinoma; ${ }^{2}$ Well differentiated ductal adenocarcinoma of the Pancreas head; ${ }^{3}$ Moderately differentiated ductal adenocarcinoma of the Pancreas head; ${ }^{4}$ Poorly differentiated adenocarcinoma of the ampulla vateri with infiltration of the pancreas; ${ }^{5}$ Adenocarcinoma of the colon; 6 Moderately differentiated adenocarcinoma of the stomach; 7 Moderately differentiated tubular adenocarcinoma of the stomach. For the tumour cell injections in the lower half of the table numbers I- 6 indicate the tumour sources of the dissociated cells. There is a significant difference between all tumours and controls and all p-values of a student $t$-test were below $0.00 \mathrm{I}$. Tumour grading and classification is according to histopathological examination. Development of micrometastases was assessed by the presence of daughter cells at 3 days post transplantation (dpt).

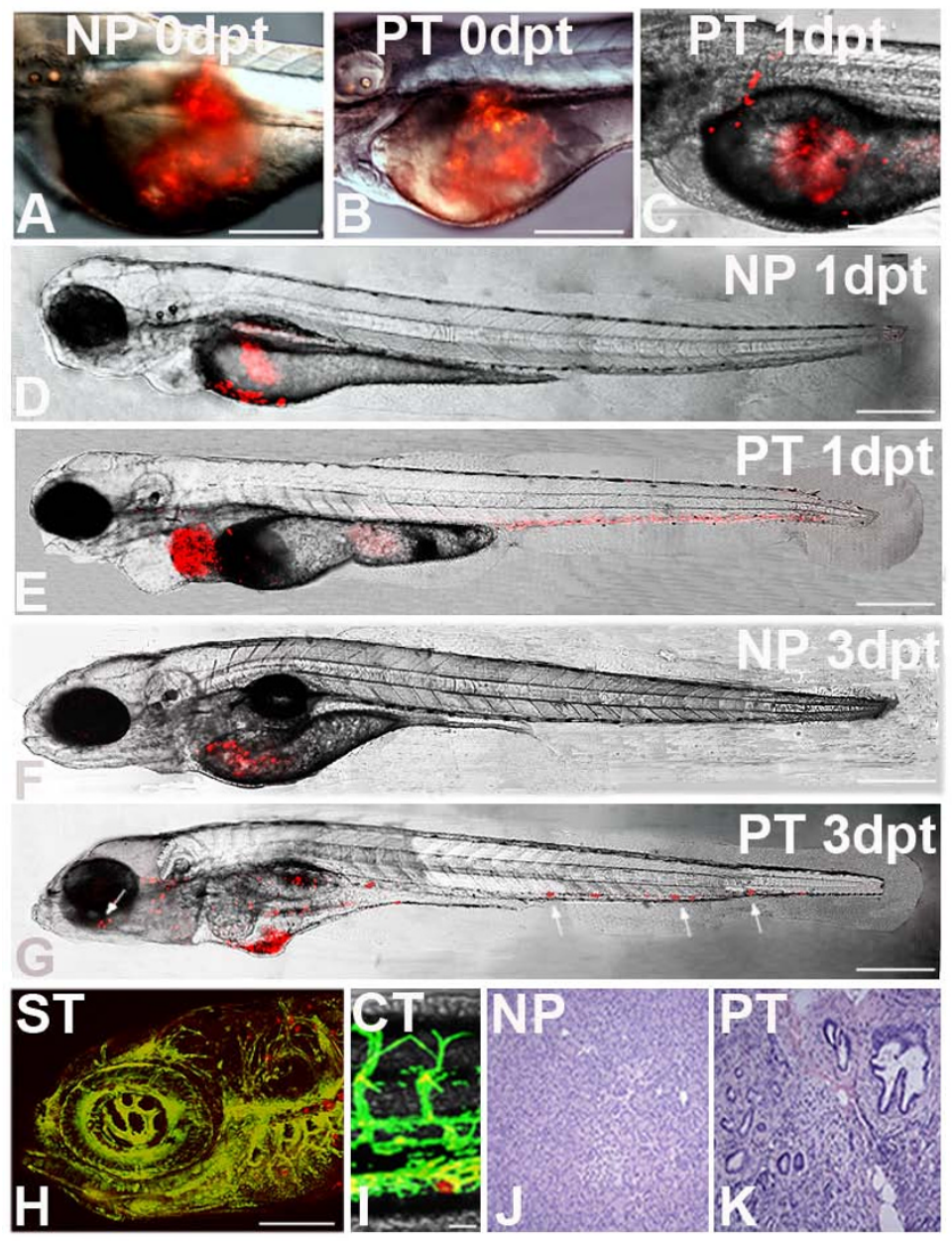

Figure 3

Tumour transplantation in zebrafish. Primary human tumours of the pancreas, the stomach and the colon were transplanted into $2 \mathrm{dpf}$ embryos. Non-tumour tissue was used as control. At the respective time points indicated laser confocal microscopy images were taken. Images A and B show newly transplanted embryos with normal pancreas (NP) and pancreatic tumour (PT) respectively. Image $C$ shows an example of an embryo transplanted with an adenocarcinoma of the pancreas at I day post transplantation (dpt) in which tumour cells have already invaded the embryo. Images $D$ to $G$ are confocal microscopy images of transplanted embryos at I dpt and $3 \mathrm{dpt}$. Normal, non-transformed pancreas transplants remain in the yolk and cells never migrate or spread in the embryo ( $D$ and $F)$. In contrast, tumour transplants show metastatic behaviour (E and $G)$. Some of the cell masses are marked with arrows, including one formed near the retina of the eye (G). On the bottom an example is shown for brain metastases of a transplanted gastric cancer (stomach tumour) in a $\mathrm{Tg}$ (flil:eGFP) zebrafish 3 days after implantation $(\mathrm{H})$. Cell masses are visible in the rhombencephalon (hindbrain) surrounding the otic capsule and near the gill arches $(\mathrm{H})$. A colon tumour transplant shows a migrated tumour cell in the caudal vein region at $3 \mathrm{dpt}(\mathrm{I})$. Both pictures $(\mathrm{H}$ and $\mathrm{I})$ were taken by confocal microscopy. HE staining of representative histological sections of normal human pancreas tissue $(\mathrm{J})$ and pancreatic cancer $(K)$ are shown. Scales shown are in A-E: $300 \mu \mathrm{m}$; F, G: $400 \mu \mathrm{m}$; in H: I00 $\mu \mathrm{m}$ and in I: $20 \mu \mathrm{m}$. 

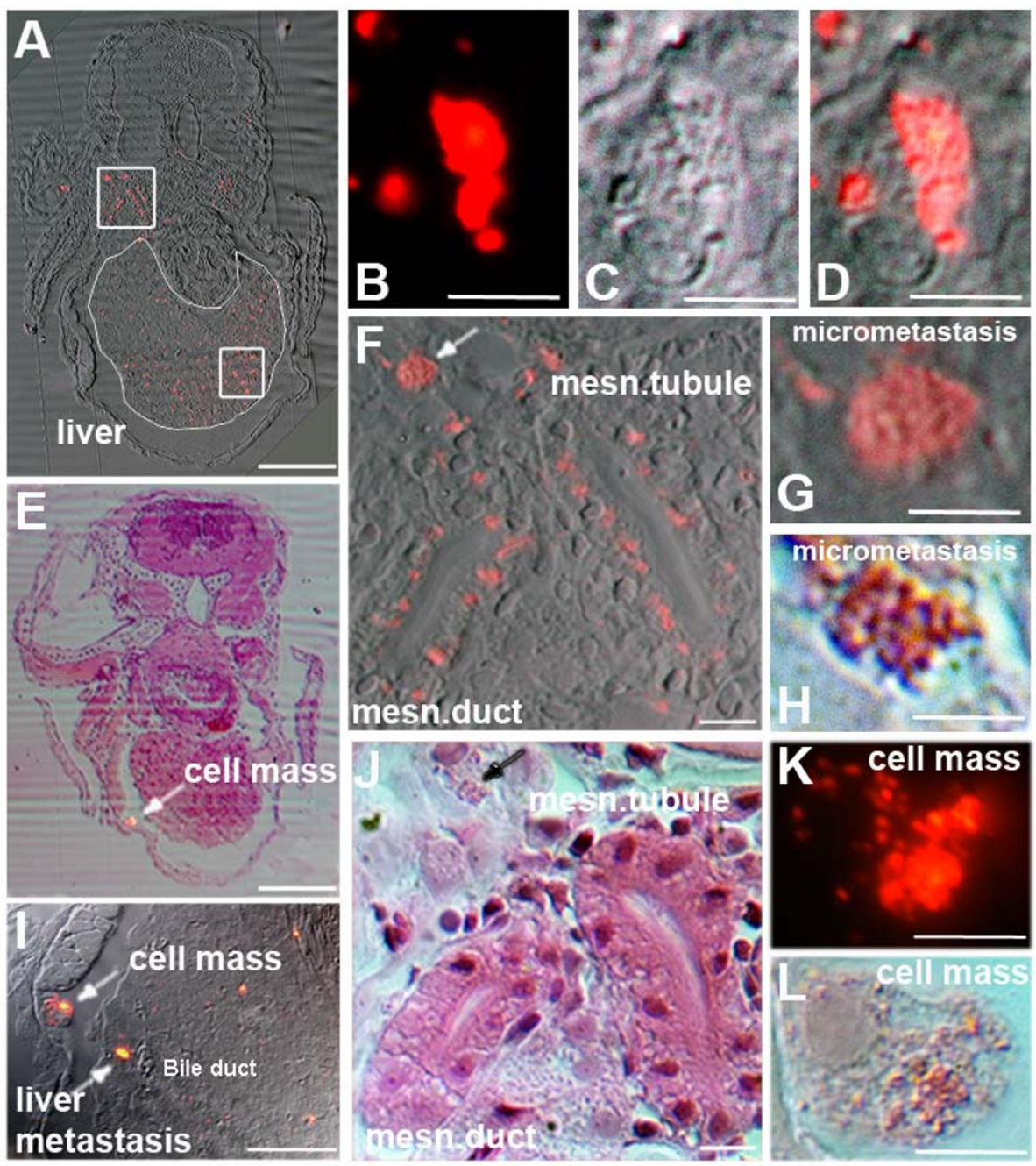

\section{Figure 4}

Histology of zebrafish embryos transplanted with a human pancreatic tumour. Transversal sections of zebrafish embryos transplanted with a primary human pancreatic tumour show the presence of micrometastases in different tissues at 3 $\mathrm{dpt}$ in 5 day old zebrafish. (A) The transversal section is approximately $40 \mu \mathrm{m}$ caudal to the anterior end of the liver. The liver is circled with a thin white line and contains many tumour cells and some micrometastases. The square in the liver contains several micrometastases, of which one is depicted in higher magnification in B (fluorescence), C (DIC) and D (overlay). The upper square shows tumour cells and micrometastases around the mesonephric tubule (msn. tubule) and the mesonephric duct (msn. duct). The enlargement of the square is shown in $\mathrm{F}$ and J (HE staining). In both, $\mathrm{F}$ (white arrow) and J (black arrow) micrometastasis is indicated (high magnifications in $\mathrm{G}$ and $\mathrm{H}$ ). In (E) HE staining of a transversal section approximately $24 \mu \mathrm{m}$ rostral to the anterior start of the liver is shown and overlayed with the fluorescent image. A larger cell mass is indicated by an arrow. The same cell mass is indicated in I in which also a liver metastasis is seen. The cell mass is shown in high magnification in $\mathrm{K}$ (fluorescent picture) and in L (HE staining). Scales shown are A and E I mm, B-D, F-H and J-L I0 $\mu \mathrm{m}$ and in I: $500 \mu \mathrm{m}$.

\section{Organotopic transplantation of primary human tumour cells in the fish liver and the effects of protease inhibitors on the invasiveness of implanted tumour cells and tumour fragments}

Some xenograft models that have been established in the mouse involve the orthotopic transplantation of specific human tumours and tumour cells $[29,30]$. Surgical orthotopic implantations (SOI) of tumour cells or of resected primary tumour fragments into immune deficient mice have proven useful for studying their growth and metastatic potential [31].

Here we transplanted freshly dissociated primary pancreatic tumour cells and normal pancreatic control cells into the liver of zebrafish larvae. For these experiments, we used the Tg(fli1:eGFP) transgenic zebrafish line (with the 

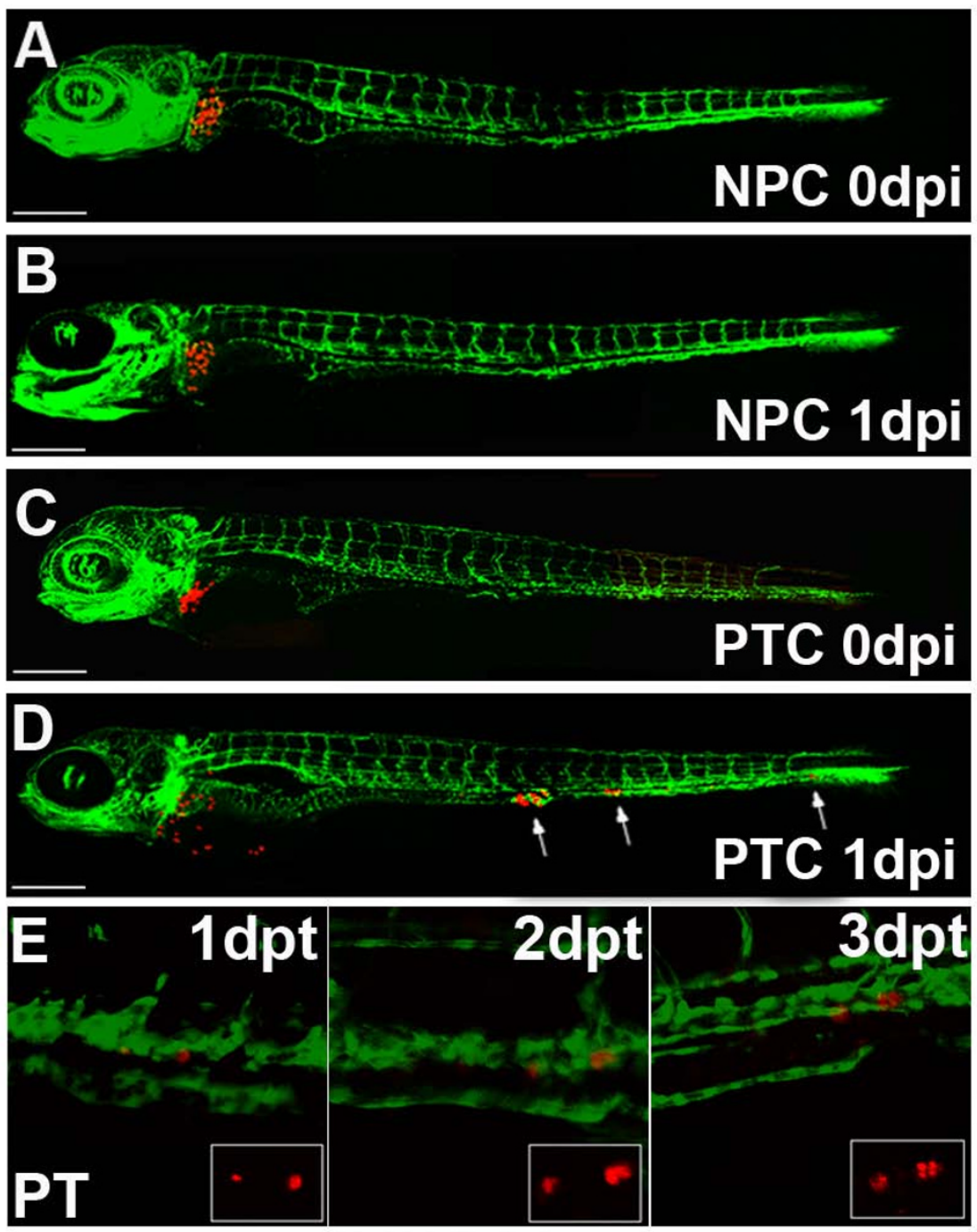

Figure 5

Implantation of primary human tumour cells into the zebrafish liver. (A-D) Organotopic implantation of primary tumour cells into the liver of larvae of Fli- I zebrafish. Representative examples of zebrafish at 5 days of development injected with primary normal pancreatic cells (NPC) and with primary dissociated pancreatic tumour cells (A and C, respectively) are shown. The same fish are depicted at I day post injection (I dpi). While normal pancreatic cells remained at the site of implantation in the liver (B), pancreatic tumour cells invaded the embryo and formed distant metastases, indicated with arrows (D). Scales indicated are: A-D $300 \mu \mathrm{m}$. Individuals were followed for up to $7 \mathrm{dpi}$ and untransformed control cells never invaded the host embryos and remained in the liver for the entire observation period (data not shown). Image E shows an example of proliferating tumour cells of a transplanted pancreatic tumour fragment on consecutive days. The single cell on the right seen at I day post transplantation is divided into two daughter cells on $2 \mathrm{dpt}$ and four cells are visible at $3 \mathrm{dpt}$. Dual colour laser scanning confocal images of the Fli-I zebrafish are shown and in the smaller insert the red fluorescence of the CM-Dil labelled tumour cells can be seen.

advantage of a fluorescent vasculature), which allows an exact localization and injection into the highly vascularised liver.
Primary cells of control pancreatic tissue, when transplanted into the liver, remained at the site of the injection and did not invade the developing zebrafish nor did they enter the blood circulation (Fig. 5). In contrast, primary tumour cells invaded the neighbouring tissue, entered the 
circulation and migrated and homed in at distant tissues and organs (Fig. 5).

Furthermore we investigated in our zebrafish xenotransplantation model the effects of protease inhibitors on the invasiveness of implanted tumour cells and tumour fragments. Two different protease inhibitors were able to inhibit the invasiveness of tumour cells and of a primary pancreatic tumour (see Additional file 1).

\section{Discussion}

Analysis of tumour metastasis in an in vivo model depends on intrinsic tumour cell properties, host factors and the experimental techniques used. The engraftment of human neoplasms in the mouse normally requires the use of nude (athymic) or severe combined immune deficient (SCID) mice that are T-and B-cell deficient. In these animal models further attention has to be paid to the site of implantation, as host factors may differ between tissues and organs. Nude mice also have an upregulated innate immunity and elevated numbers of natural killer cells and tumoricidal macrophages, which may limit tumour growth or even prevent metastasis. Efficacy of pharmacological and toxicological studies in murine xenograft models normally use tumour growth, body weight loss and mortality as parameters of toxicity. These studies are cumbersome, time consuming and drug activity against xenografts does not always correlate with its clinical activity [32].

In our study we established the zebrafish as a robust in vivo model for investigating invasiveness and metastatic behaviour of human primary tumours. It is known that early zebrafish embryos do not reject xenotransplanted human cells [13-15], whereas 1 month old zebrafish already need to be immune suppressed [11].

The early embryos and larvae used here did not reject the primary tumour xenografts, most likely due to the fact that their immune system is not fully developed. It has been observed that while lymphopoiesis and lymphoidorganogenesis are initiated at the middle to late embryo period, they remained in their rudimentary and immature form throughout the early larval stages. The major maturation events leading to immune competence occur between 2 and 4 weeks post fertilisation (wpf), coinciding with the larval to juvenile transitory phase [33].

The observed metastasis in an animal model primarily should reflect the intrinsic metastatic ability of the tumour cells, but may depend to some extent also on the experimental system. Other experimental animal systems have demonstrated that only a small subset of metastatic cells (approximately 2\%) survive and grow at secondary sites [34]. The significantly higher percentage of microme- tastases observed using fish embryos may in part reflect the absence of the humoral immune response and/or other selective pressures on tumors cells which would lead to tumor cell death following extravastaion into secondary

organs.

The transparency of the fish embryo enables an investigation of fluorescently labelled tumour cells in real time and at high resolution. The unique availability of transgenic zebrafish without a functional vasculature [17] further allowed us to show that the metastatic spread of tumour cells in zebrafish embryos involves the vascular system. Even the very early steps of invasion, circulation of tumour cells in blood vessels, colonization at secondary organ sites and metastasis formation can be observed this way-something which to date cannot be investigated in established mouse tumour models. Advantages of the model system such as good accessibility, easy handling, low costs and short incubation times make it a promising system for future functional studies in primary tumours.

The experiments described here provide the basis for the future development of a screening methodology of drugs, which inhibit invasion and metastasis of human tumours. Recently, adult zebrafish with an almost entirely transparent body have been described, as a novel tool for in vivo transplantation analysis [35]. These will be of interest for additional comparative analysis of metastasis formation of primary tumours in the immune competent animal.

\section{Conclusion}

We demonstrate here the applicability of the zebrafish embryo as an in vivo model for the analysis of metastatic behaviour of human tumour cells, including resection specimen from human tissue. High resolution imaging of live zebrafish has and will further assist in better understanding the underlying mechanisms of cancer cell invasion and metastasis formation. Advantages of the model system such as good accessibility, easy handling, low costs and rapidness are unparalleled by other vertebrate organisms and make it a promising system for future functional studies in primary tumours. The advantages of the "short term" zebrafish embryo model could nicely complement established "longer term" tumour models, e.g. mouse models, and may be a valuable and efficient tool to evaluate novel therapeutic strategies for cancer.

\section{Competing interests statement}

The authors declare that they have no competing interests.

\section{Authors' contributions}

IJM, FUW, CN, LIP, CDH, MML and CPB did experimental work and helped with writing the manuscript. CPB did project planning and wrote the manuscript. All authors read and approved the final manuscript. 


\section{Additional material}

\section{Additional file 1}

Supplemental Tables. Tables of all experiments including tumour transplantations and injections of primary tumor cells, control tissues, EpRas and EpRasTGF- $\beta$ cells, PaTu-S and PaTu-T cells, Protease inhibitor treated cells and benign tumours (Colon Polyps).

Click here for file

[http://www.biomedcentral.com/content/supplementary/14712407-9-128-S1.doc]

\section{Additional file 2}

EpRas cells. 3D reconstruction of EpRas cells in the yolk at 3dpi (20x magnification).

Click here for file

[http://www.biomedcentral.com/content/supplementary/1471-

2407-9-128-S2.mpg]

\section{Additional file 3}

TGF- $\beta$ treated EpRas cells. 3D reconstruction of EpRas TGF- $\beta$ treated cells in the dorsal aorta at 3dpi (20x magnification).

Click here for file

[http://www.biomedcentral.com/content/supplementary/1471-

2407-9-128-S3.mpg]

\section{Additional file 4}

Time lapse movie of implanted TGF- $\beta$ treated EpRas cells. Supplemental Movie 1: Time lapse movie (rate: 1 frame/minute) showing EpRas TGF- $\beta$ cells which have invaded the zebrafish body, have translocated into the vasculature and have colonized distant sites in the 5 day old larvae. Some cells are visible in the blood stream whereas others have extravasated from the vasculature.

Click here for file

[http://www.biomedcentral.com/content/supplementary/1471-

2407-9-128-S4.mpg]

\section{Additional file 5}

Wound healing in vitro migration assay ("scratch assay"). Cell-based in vitro migration assay for PaTu-S and PaTu-T cells.

Click here for file

[http://www.biomedcentral.com/content/supplementary/14712407-9-128-S5.doc]

\section{Additional file 6}

Lack of circulation in cloche-/- mutants. Real time movie of control fish and cloche- fish at $3 \mathrm{dpf}(1 \mathrm{dpi})$. The movie shows a control fish with a beating heart and with visible circulating blood cells. The second part of the movie illustrates a cloche-- fish with a beating heart. No circulation is observable in the mutant fish; the third part of the movie is a higher magnification of a control fish in the area of the blood islands and tail, showing cells circulating in the vasculature e.g. caudal vein, dorsal aorta and intersegmental vessels. The last part of the movie shows a higher magnification of a cloche-1-fish in the same area of the blood islands as the control. In contrast to the control zebrafish, the cloche-/ fish does not possess a functional vascular system and shows no sign of circulation.

Click here for file

[http://www.biomedcentral.com/content/supplementary/14712407-9-128-S6.mpg]

\section{Additional file 7}

No metastatic behaviour of implanted tumour cells in cloche mutant embryos. PaTu-T cells injected into control and cloche-/ embryos.

Click here for file

[http://www.biomedcentral.com/content/supplementary/14712407-9-128-S7.tiff]

\section{Additional file 8}

PCNA staining. Whole mount immunofluorescence of a pancreatic tumour transplanted embryo.

Click here for file

[http://www.biomedcentral.com/content/supplementary/14712407-9-128-S8.tiff]

\section{Additional file 9}

Circulation of pancreatic tumour cells. Real-time movie of pancreatic tumour cells in the zebrafish 1 day after a pancreatic cancer fragment was transplanted. Circulating tumour cells and tumour cells which have extravasated into the perivascular tissue of a 3 day old zebrafish are visible. A moving primary human tumour cell passing through the caudal vein and into an intersegmental vessel is also visible.

Click here for file

[http://www.biomedcentral.com/content/supplementary/14712407-9-128-S9.mpg]

\section{Additional file 10}

Tumour cell in the vasculature. Real-time movie of a pancreatic cancer cell slowly traversing through the vasculature (the caudal vein) of a $\mathrm{Tg}$ (fli1:eGFP) zebrafish embryo.

Click here for file

[http://www.biomedcentral.com/content/supplementary/1471 2407-9-128-S10.mpg

\section{Acknowledgements}

We would like to thank G. Posern for supplying the mouse cells, Davy de Witt for his part of animal welfare and Joost Woltering and Jaya Besser for critical remarks on the manuscript. We would further like to acknowledge and thank the Tübingen 2000 Screen Consortium and Exelixis, as the original source of the cloche mutant embryos. This work was supported by grants from the Portuguese foundation for Science and Technology (SFRH/ BD/27262/2006), the Deutsche Krebshilfe (10-203I-Le) and the AlfriedKrupp-Foundation.

\section{References}

I. Jemal A, Siegel R, Ward E, Murray T, Xu J, Thun MJ: Cancer Statistics, 2007. CA Cancer J Clin 2007, 57(I):43-66.

2. Fidler IJ: The pathogenesis of cancer metastasis: the 'seed and soil' hypothesis revisited. Nat Rev Cancer 2003, 3(6):453-458.

3. Zon LI, Peterson RT: In vivo drug discovery in the zebrafish. Nat Rev Drug Discov 2005, 4(I):35-44.

4. Kari G, Rodeck U, Dicker AP: Zebrafish: An Emerging Mode System for Human Disease and Drug Discovery. Clin Pharmacol Ther 2007, 82(I):70-80.

5. den Hertog J: Chemical Genetics: Drug Screens in Zebrafish. Bioscience Reports 2005, 25(5):289-297.

6. Parng C, Seng WL, Semino C, McGrath P: Zebrafish: A Preclinical Model for Drug Screening. ASSAY and Drug Development Technologies 2002, I(I):4I-48.

7 Goessling W, North TE, Zon LI: New Waves of Discovery: Modeling Cancer in Zebrafish. J Clin Oncol 2007, 25(I7):2473-2479.

8. Hendrix MJC, Seftor EA, Seftor REB, Kasemeier-Kulesa J, Kulesa PM, Postovit L-M: Reprogramming metastatic tumour cells with 
embryonic microenvironments. Nat Rev Cancer 2007, 7(4):246-255.

9. Grunwald DJ, Eisen JS: Headwaters of the zebrafish [mdash] emergence of a new model vertebrate. Nat Rev Genet 2002, 3(9):717-724.

10. Langenau DM, Traver D, Ferrando AA, Kutok JL, Aster JC, Kanki JP Lin S, Prochownik E, Trede NS, Zon LI, et al.: Myc-Induced T Cell Leukemia in Transgenic Zebrafish. Science 2003, 299(5608):887-890.

II. Stoletov K, Montel V, Lester RD, Gonias SL, Klemke R: High-resolution imaging of the dynamic tumor cell vascular interface in transparent zebrafish. Proc Natl Acad Sci U S A 2007 104(44): |7406-|74II.

12. Lee Lisa MJ, Seftor EA, Bonde G, Cornell RA, Hendrix MJC: The fate of human malignant melanoma cells transplanted into zebrafish embryos: Assessment of migration and cell division in the absence of tumor formation. Developmental Dynamics 2005, 233(4): 1560-1570.

13. Topczewska JM, Postovit L-M, Margaryan NV, Sam A, Hess AR, Wheaton WW, Nickoloff BJ, Topczewski J, Hendrix MJC: Embryonic and tumorigenic pathways converge via Nodal signaling: role in melanoma aggressiveness. Nat Med 2006, I 2(8):925-932.

14. Haldi M, Ton C, Seng W, McGrath P: Human melanoma cells transplanted into zebrafish proliferate, migrate, produce melanin, form masses and stimulate angiogenesis in zebrafish. Angiogenesis 2006, 9(3): $139-151$.

15. Nicoli S, Ribatti D, Cotelli F, Presta M: Mammalian Tumor Xenografts Induce Neovascularization in Zebrafish Embryos. Cancer Res 2007, 67(7):2927-293I.

16. Nicoli S, Presta M: The zebrafish/tumor xenograft angiogenesis assay. Nat Protoc 2007, 2(I I):2918-2923.

17. Herpers R, Kamp E van de, Duckers HJ, Schulte-Merker S: Redundant Roles for Sox7 and Sox 18 in Arteriovenous Specification in Zebrafish. Circ Res 2008, I02(1):12-15.

18. Liang C-C, Park AY, Guan J-L: In vitro scratch assay: a convenient and inexpensive method for analysis of cell migration in vitro. Nat Protoc 2007, 2(2):329-333.

19. te Velthuis AJW, Ott EB, Marques IJ, Bagowski CP: Gene expression patterns of the ALP family during zebrafish development. Gene Expression Patterns 2007, 7(3):297-305.

20. Marques I, Leito J, Spaink H, Testerink J, Jaspers R, Witte F, Berg S van den, Bagowski C: Transcriptome analysis of the response to chronic constant hypoxia in zebrafish hearts. Journal of Comparative Physiology B: Biochemical, Systemic, and Environmental Physiology 2008, I 78(I):77-92.

21. Oft M, Peli ], Rudaz C, Schwarz H, Beug H, Reichmann E: TGF-beta I and Ha-Ras collaborate in modulating the phenotypic plasticity and invasiveness of epithelial tumor cells. Genes Dev 1996, I O(I9):2462-2477.

22. Oft M, Heider K-H, Beug H: TGF[beta] signaling is necessary for carcinoma cell invasiveness and metastasis. Current Biology 1998, 8(23): I243-1252.

23. Waerner T, Alacakaptan M, Tamir I, Oberauer R, Gal A, Brabletz T, Schreiber M, Jechlinger M, Beug H: ILEI: A cytokine essential for EMT, tumor formation, and late events in metastasis in epithelial cells. Cancer Cell 2006, 10(3):227-239.

24. Lawson ND, Weinstein BM: In Vivo Imaging of Embryonic Vascular Development Using Transgenic Zebrafish. Developmental Biology 2002, 248(2):307-318.

25. Elsässer H, PL U, Agricola B, Kern HF: Establishment and characterisation of two cell lines with different grade of differentiation derived from one primary human pancreatic adenocarcinoma. Virchows Arch B Cell Pathol Ind Mol Pathol 1992 6 I(5):295-306.

26. Menke A, Philippi C, Vogelmann R, Seidel B, Lutz MP, Adler G, Wedlich D: Down-Regulation of E-Cadherin Gene Expression by Collagen Type I and Type III in Pancreatic Cancer Cell Lines. Cancer Res 200I, 6I(8):3508-35I7.

27. Mayerle J, Schnekenburger J, Kruger B, Kellermann J, Ruthenburger M, Weiss FU, Nalli A, Domschke W, Lerch MM: Extracellular Cleavage of E-Cadherin by Leukocyte Elastase During Acute Experimental Pancreatitis in Rats. Gastroenterology 2005, I 29(4): I 25I-1267.

28. Cha D, OB P, O'Toole EA, Woodley DT, Hudson LG: Enhanced modulation of keratinocyte motility by transforming growth factor-alpha (TGF-alpha) relative to epidermal growth factor (EGF). J Invest Dermatol 106(4):590-597.

29. Sharpless NE, DePinho RA: The mighty mouse: genetically engineered mouse models in cancer drug development. Nat Rev Drug Discov 2006, 5(9):74I-754.

30. Frese KK, Tuveson DA: Maximizing mouse cancer models. Nat Rev Cancer 2007, 7(9):654-658

31. Hoffman R: Orthotopic metastatic (MetaMouse) models for discovery and development of novel chemotherapy. Methods Mol Med 2005, I I I:297-322.

32. Johnson JI, S D, Zaharevitz D, Rubinstein LV, Venditti JM, Schepartz S, Kalyandrug S, Christian M, Arbuck S, Hollingshead M, Sausville EA: Relationships between drug activity in $\mathrm{NCl}$ preclinical in vitro and in vivo models and early clinical trials. British Journal of Cancer 200 I, 84: | 424-| 43|.

33. Lam SH, Chua HL, Gong Z, Lam TJ, Sin YM: Development and maturation of the immune system in zebrafish, Danio rerio: a gene expression profiling, in situ hybridization and immunological study. Developmental \& Comparative Immunology 2004, 28(I):9-28.

34. Weiss L: Metastatic inefficiency. Adv Cancer Res 1990, 54:159-2II

35. White RM, Sessa A, Burke C, Bowman T, LeBlanc J, Ceol C, Bourque C, Dovey M, Goessling W, Burns CE, et al:: Transparent Adult Zebrafish as a Tool for In Vivo Transplantation Analysis. Cell Stem Cell 2008, 2(2): 183-189.

\section{Pre-publication history}

The pre-publication history for this paper can be accessed here:

http://www.biomedcentral.com/1471-2407/9/128/pre pub

Publish with Biomed Central and every scientist can read your work free of charge

"BioMed Central will be the most significant development for disseminating the results of biomedical research in our lifetime. "

Sir Paul Nurse, Cancer Research UK

Your research papers will be:

- available free of charge to the entire biomedical community

- peer reviewed and published immediately upon acceptance

- cited in PubMed and archived on PubMed Central

- yours - you keep the copyright
BiolMedcentral 